\title{
Noen som kunne tenke seg å være turnuslege for en uke?
}

\author{
Livet er deilig. Lykkelig som turnuslege i distrikt!
}

Det er mandag og jeg er i ferd med å avslutte dagens arbeidsoppgaver. Mannen min har hentet guttungen vår på 14 måneder $\mathrm{i}$ barnehagen, og jeg kan ta meg god tid til å avslutte dagens arbeid og forberede meg på ettermiddagen som venter meg hjemme. Jeg er selvfølgelig av det oppofrende legeslaget og har full forståelse for at mannen min vil på kurs i en uke. Han er jo også lege, under spesialisering nå, og jeg skysser ham av gårde for en ukes kurs i hovedstaden. Jeg skal jo styre skipet hjemme, ikke noe problem, jeg er supermamma, karrierekvinnen som alltid beholder roen og besinnelsen overfor sønnen min!

Ettermiddagen er lang, guttungen sutrer, han er trett. Jeg lar ham ikke sovne før klokken er godt passert sju på kvelden. Nå skal jeg ha kvalitetstid for meg selv. Stor kopp te på bordet, stearinlys og nyeste utgave av Tidsskriftet. Vrcel! Det er guttungen som er våken. Herre fred, han har jo bare sovet i tre kvarter! Jeg lister meg opp bysser, synger, gynger, traller og laller. Han får pupp, han får kos, han står på hodet, han står på hodet mitt! Hjelp, jeg er på vei til å miste kontrollen. Jeg snakker til ham med streng stemme: «Elias, det er natten nå, alle små barn skal sove, du også!» Det går til sammen to timer. Endelig sover han. Jeg kaster ut den kalde teen med melkesnerk i, blåser ut stearinlys og ser lengselsfullt på Tidsskriftet. Jeg tenker at jeg får ta det i morgen, jeg har jo tross alt en hel uke på meg!

Dag to og dag tre forløper nokså likt. Guttungen våkner før seks, vi har «herlig morgenkos» før jeg kaster ham i bilsetet og kjører av gårde til barnehagen. Ungen skriker, han vil være med mamma. Jeg er allerede for sent ute. Pasientene venter. Jeg tar på meg legefrakken og jobber i et forrykende tempo. Her er det ikke rom for «tea breaks». Tanken på «tvangsplassering»av ungen min i barnehagen vokser til en stor vond klump i magen. Den siste pasienten for dagen dumper inn på kontoret. Du vil ha sykmelding, sa du? Ja, vondt i ryggen, var det ikke det? Ja ha, klarer ikke utføre noe arbeid i det hele tatt. Men du kom jo syklende hit? OK, jeg orker ikke krangle i dag heller. To uker, gå hjem og hvil deg!

Jeg sier til meg selv at jeg er en omsorgsfull turnuslege. Lovordet fra studietiden «do no harm» er alltid gjeldende.

Om kvelden ryker alle planer om alenetid. Igjen. Han vil ikke sove og hyler. Vi legger oss sammen i mamma og pappas seng. Helt $\mathrm{OK}$, det. Han er våken fra kl 0100 til kl 0330 begge netter. Jeg ser stjerner om morgenen. Det fine er jo at de forteller at han hver dag sover som en drøm i barnehagen!

Dag fire er rent sagt et helvete. Det er nonstopsutring fra jeg henter ham i barnehagen til han endelig sover for natten. Jeg er helt utslitt. Våkner påfølgende dag og har dårlig tid. Elias, vi dropper frokost $i$ dag, $d u$ får spise i barnehagen! Supermammaen i meg får en enda mindre stjerne. Det er kaldt og mørkt ute, jeg er fra Østlandet og kjenner jeg savner snøen til å lyse opp. Å nei. Jeg står bare med store øyne og ser på venstre fremdekk. Det er punktert.
Supermamma finner alltid en løsning. Opp i vognen, heldigvis er det en brødskalk han kan gnage på, stakkars, han har jo ikke fått frokost ennå. Buss til barnehagen. Buss til jobb. Buss fra jobb til barnehagen og hjem igjen. Jeg lager fiskeboller til middag uten poteter og gulrøtter (vi har ikke tid til å vente på at de blir kokt!) Jeg er blek, uten sminke, har heller ikke hatt tid til å dusje denne uken. I morgen kommer pappa, Elias! Et stort smil møter meg. Litt grønn snørr under nesen og rester av middagen på begge kinn. Han er verdens største sjarmtroll!

Vi legger oss for natten, sammen. Han sovner som en liten engel ved siden av meg. Jeg stryker de deilige små hendene. Nye pasienter, sykmeldinger og andre spennende utfordringer venter på meg neste morgen! Jeg hviler hodet på puten, verdens største takknemlighet kommer over meg. Jeg er supermamma og karrierekvinne, er jeg ikke?!

\section{Camilla Stadheim Hellum camillastadheim@gmail.com Køhler legesenter Langflåtveien 33 4017 Stavanger}

Innlegget er tidligere publisert i Syd-Vesten nr. 4/2009, medlemsbladet til Rogaland legeforening.

Oppgitte interessekonflikter: Ingen

Manuskriptet ble mottatt 21.12. 2009 og godkjent 21.1. 2010. Medisinsk redaktør Erlend Hem. 